\title{
Application of the Business Administration Specialty Teaching
}

\author{
Tian Yi \\ School of Business Yangzhou University, Yangzhou, Jiangsu, China \\ jstianyi@163.com
}

\begin{abstract}
Keywords: Business administration; The problems in teaching; New economy
\end{abstract}
\begin{abstract}
There are many problems in the teaching of Business Administration Specialty. For example, the backward education concept, the obsolete teaching content, the method of teaching being too mechanical, the backwardness of teaching ideas, and so on. We can solve these problems by the introduction of modern teaching methods, strengthening construction of practice base, and implementing the tutorial system.
\end{abstract}

\section{Characteristics of Professional Business Management}

According to the Ministry of Education in 2012 September promulgated the "ordinary college undergraduate professional directory" (2012). Business Administration belongs to the discipline of management science under the first level discipline, including marketing, accounting, financial management, international business, human resource management, auditing, assets evaluation, property management, cultural industry management nine two level of discipline. Business management professional development needs of the modern market economy, with the humanistic spirit, scientific literacy and credible quality, master the modern management theory, method and application of tools, have discipline foundation generous, have certain innovation ability, practice ability, cooperation ability and self-developing ability, with international vision, innovation consciousness, team spirit, skilled use of the network technology of the computer and English, advanced applied talents engaged in management work in the manufacturing industry, service industry, financial industry all types of enterprises, institutions and government departments. The basic theory and application tool the professional requirements of students to master the general management system, function of management, master the basic method of business administration, has found the problem, the comprehensive ability of analysis and solving problems, with the thinking of management innovation.

\section{The Characteristics of Human Resources Demand in the New Economic Era}

Social Development Has Become more and more Intelligent. In the era of new economy society is a learning society, creation, dissemination and application of activities more and more people will be engaged in knowledge, and create wealth for the society through these activities. In this society, the knowledge management ability becomes the key to the core competitiveness of enterprises; knowledge has become the source of enterprise competitive advantage. Schools and enterprises should pay more attention to cultivate and motivate the knowledge type talents, and strive to improve their ability of knowledge management. [1]

The Transmission of Information is Going Online. The rise of the Internet and electronic data interchange (EDI) technology is widely used, so that the world into a "global village" era created a limited by geographical boundary and binding work environment and vision. The rapid development of emerging technologies, not only improves the management efficiency of enterprises, greatly reducing the transaction cost, but also has had a huge impact on the enterprise management. [2] The development of technology not only redefines the working time and the working mode, and even re build organization structure. The rapid development of information technology makes the enterprise more and more aware of the importance of people.

The Staff Structure Presents the Pluralistic Characteristic. With the further standardize the development of the process of national modernization and the labor market; the flow of personnel 
will inevitably become more frequent, part of enterprise staff more complex. Because the education degree of different types of employees to accept different, the growth of different cultural background, their knowledge, skills and values, work motivation, demand presents the obvious differences. [3] With different knowledge skills and quality of employees is different for different enterprise value, employee compensation form will also be different.

Changes in the new economic era of human resources and social needs put forward new requirements for business management specialty teaching. It requires a business management major is to train applied talents and compound talents. This requires further attention to the teaching of business management; strengthen practice teaching, so as to cultivate qualified talents for the society.

\section{The Existing Problems in the Teaching of Business Administration Specialty}

Backwardness of Teaching Ideas. Over the years, the College of Business Administration Specialty in our country exists generally focuses on theory, light practice ideas. In the practical teaching of most universities MBA, theory teaching still plays a dominant role, practice teaching is added, and even embellishment. [4] But the training goal of business management is to cultivate the practical application of talent, the existing educational concept makes the basic does not have the professional skills of the students effectively, resulting in a significant disconnect between school culture and market demand.

Teaching Material Obsolescence, Diversifies Lack, the Teaching Means Backward. At present business management specialty teaching in China basically is the implementation of the teaching method of Teacher centered teaching method. The teaching method has some limitations: if not to arouse students' attention and interest in the use of, and can inspire students' thinking and imagination, vulnerable to the formation of cramming method of teaching; teachers level affects the teaching effect directly, easily lead to the gap between theory and practice; the one-way communication, passive, mechanical and single point to by teachers students, easy to cause the separation and isolation of the learning process. Many teachers and obsolete teaching content, method, means a single backward, is worried about is difficult to adapt to the high requirements of modern teaching proposed on knowledge structure, professional level, teaching method, unwilling to pay a huge effort to change the old teaching mode, also worry that students cannot adapt to the modern teaching methods affecting the normal teaching order, and the lack of passion and the power of modern teaching.

The Students Lack the Ability of Autonomous Learning. Students receiving long-term traditional indoctrinating teaching, in the face of modern teaching methods, generally adapt ability is not strong, put forward to treat the problems in the case be at a loss what to do. Most of the students in the group discussion often exhibit knowledge is too narrow, the ability of poor thinking ability and language expression.

\section{Some Suggestions}

The Introduction of Modern Teaching Methods. Seminar teaching originates from Germany, has become the modern western countries in undergraduate teaching is very important and widely used teaching mode. [5] This model has definite teaching aim, teaching plan and teaching content, forms a complete teaching system, it has become a standard, internal rules of the teaching paradigm. It refers to the students under the guidance of Professor, is a subject forms a group, based on a great deal of investigations and teachers freely for academic study, so as to achieve the dual purpose of teaching and scientific research. It advocates that teachers between the combination of teaching and scientific research, academic freedom of teachers and creative spirit of cooperation, equality between teachers and students, pay attention to the cultivation of students' ability. The macro structure of Seminar curriculum consists of two major summaries about teachers and monographic study. In the first part, the teacher will systematically and comprehensively introduces the historical development vein, the development background of subject frontier subjects show, let students 
understand the main representative figures in this field and its main ideas and propositions related topic summary of outline of this course will be discussed, and assign them to the relevant participating students, provide a solid theoretical foundation and necessary technical foundation for the second part. The second part is the main course of exchange. In this part, the students according to their research orientation and academic interest, teaching contents will be claimed to make full preparations, become a theme speaker report. The report must distribute their speeches to print every course participants in advance. The organization design is a required professional basic course for undergraduate students of business administration. The author has been engaged in the teaching work. The author in the business and professional management of the school in the third grade class teaching two classes a full 90 minutes to try the Seminar teaching method, has received the good effect.

Strengthening Construction of Practice Base. Practice base has a greater effect on the students improve their practical ability to work. If the students can in theory study immediately after binding to the actual business, not only can make the theoretical knowledge of students get distillation, but also can make the students improve their practical ability, will also encourage students to recognize the importance of theoretical study, to promote the role of students' knowledge and the accumulation of reserves play.

Implementing the Tutorial System .On the one hand, the current teaching content of business administration older, cannot adapt to the new requirements of the social, economic, scientific and technological development, made some defects and deficiencies of the culture on the college students' knowledge structure. On the other hand, the professional school students lack the necessary guidance and guidance, leading to stand on one's own ability is poor, lack of team spirit and cooperation with others, not good at independent thinking, innovation ability, the problem of insufficient. The lack of focus on performance for students entering the graduation thesis writing stage after a loss, do not know how the topic, do not know how to retrieve references, do not know what to look for books, do not know how to read a book. Instructor in thesis guidance process just one semester, it is difficult to fully, effectively improve the skills of students. In view of the above situation, we think it is necessary to carry out the tutorial system in the industrial and commercial management specialty teaching. From the beginning of the students to the school, the two-way choice and overall coordination control principle, by the student and teacher for a two-way choice, determine the class all the students' learning tutor. The tutor responsible for guiding the students learning activities, guide the students to conduct scientific research, guidance in the conditions allow students to engage in horizontal topic research activities, and is responsible for directing the students' graduation thesis.

\section{Acknowledgement}

This research was financially supported by the Yangzhou University Foundation (Grant YZUJX2017-62C)

\section{References}

[1] Meng Xianglin, Research on human resource management of College Innovation, Journal of Yangzhou University, vol.2, pp.15-18, 2011.

[2] Tian Yi, Preliminary consideration of small and medium-sized private enterprises human resources management in new economic era, The vitality of enterprises, vol.9, pp.35-39, 2008.

[3] Li Hengchuan, Study on innovation of training pattern reform of personnel under the view of Higher Education, Journal of Yangzhou University, vol.4, pp.75-78, 2012.

[4] Ren Peijiang, Higher education quality guarantee and supervision from the perspective of teachers in Colleges and Universities, Journal of Nanjing University, vol.2, pp.117-118, 2010.

[5] Wang Mingyi, The seminar of Germany and the teaching of Modern University, Foreign education research, Vol. 7, pp.21-32, 2010. 